\title{
地域包括ケア時代の臨床研究を担う人材の育成
}

\author{
赤沢学
}

\section{Clinical Research in Communities and the Importance of Patient Information}

\author{
Manabu Akazawa \\ Meiji Pharmaceutical University; 2-522-1 Noshio, Kiyose, Tokyo 204-8588, Japan.
}

(Received August 16, 2021)

\begin{abstract}
In collaboration with community pharmacists, we have conducted research including drug utilization reviews since 2009 and patient registry and long-term follow-up since 2013. The results of these projects have influenced the establishment of healthcare policies and pharmacists' roles. Moreover, the number of clinical studies using electronic medical records by hospital pharmacists has increased. Findings from real-world clinical practice provide useful evidence to improve the quality of patient care provided by clinical pharmacists. When comparing research between community and hospital pharmacists, differences are observed in the efficiency of using patients' information. In hospitals, patients' medical records are important for sharing information among healthcare providers. However, in communities, the importance of maintaining patients' information tends to follow dispensing medications and counseling. This practice results in a lack of data for clinical research. Studies in community pharmacies would deepen our understanding of the needs for patient records and improve the quality of patient care.
\end{abstract}

Key words — clinical research; quality of care; drug utilization review; patient registry; long-term follow-up; electronic medical record

\section{1.はじめに}

薬学教育が 6 年制になってから博士号を目指す薬 局・病院薬剂師が増えている。私の研究室（公衆衛 生・疫学研究室 : https://u-lab.my-pharm.ac.jp/ 〜 pharmepi/）には, 約 20 名の大学院生・研究生 が所属し, そのほとんどが仕事をしながら学ぶ社会 人である。そのため研究テーマは自らの実務経験の 中から興味を持った臨床疑問をべースに, 研究可能 なリサーチクエスチョンにまとめることから始め る. 研究デザインや医療統計について基礎から学ぶ 人も少なくない。残念ながら薬学教育の中では臨床 研究のやり方を学ぶ機会が限られている。 そのため 医療現場の薬剂師が, さて臨床研究でもやってみよ うと思っても，どこから手をつけてよいのか分から ないのが現状ではないだろうか？

本稿では，地域医療で活躍する多くの薬局薬剤師 と一緒に行ったブラウンバッグ運動と薬剤師中間介

明治薬科大学 (T204-8588 東京都清瀬市野塩 2-522-1) e-mail: makazawa@my-pharm.ac.jp

本総説は, 日本薬学会第 141 年会シンポジウム S28 で 発表した内容を中心に記述したものである.
入研究を振り返りながら, 薬剤師が行う臨床研究の 課題についてまとめる。 また，近年増えてきている 病院薬剂師が医療機関の患者記録を用いた疫学研究 について紹介し, 薬局薬剂師による先行研究との比 較から, 今後の薬剤師が行う臨床研究の意義につい て考察する.

\section{2. ブラウンバッグ運動（2009 年～）}

ブラウンバッグ運動は, 米国で 1980 年代に始 まった活動で, 患者が日常的に服用している薬（処 方薬，OTC 薬，サプリメントなど）を茶色い紙袋 に入れて薬局に持参してもらい，薬剤師が飲み合わ せや服薬状況に問題がないかを確認する薬局のサー ビスである．高齢者に不適切な処方薬の使用実態を 調べたレセプト研究を行った経験から, ${ }^{1)}$ OTC 薬や サプリメントを含めた服用薬全体について使用実態 を調べたいと思った．そこで東京大学の先生方と一 緒に高齢者薬物治療適正化研究グループを立ち上げ, 2009 年に広島県から日本独自のブラウンバッグ運 動を始めた (Fig. 1). ${ }^{2-4)}$ 県医師会, 県薬剂師会, 広島大学, 広島県で組織された広島県地域保健対策 協議会（地対協）の支援を受けて，177 の薬局に参 


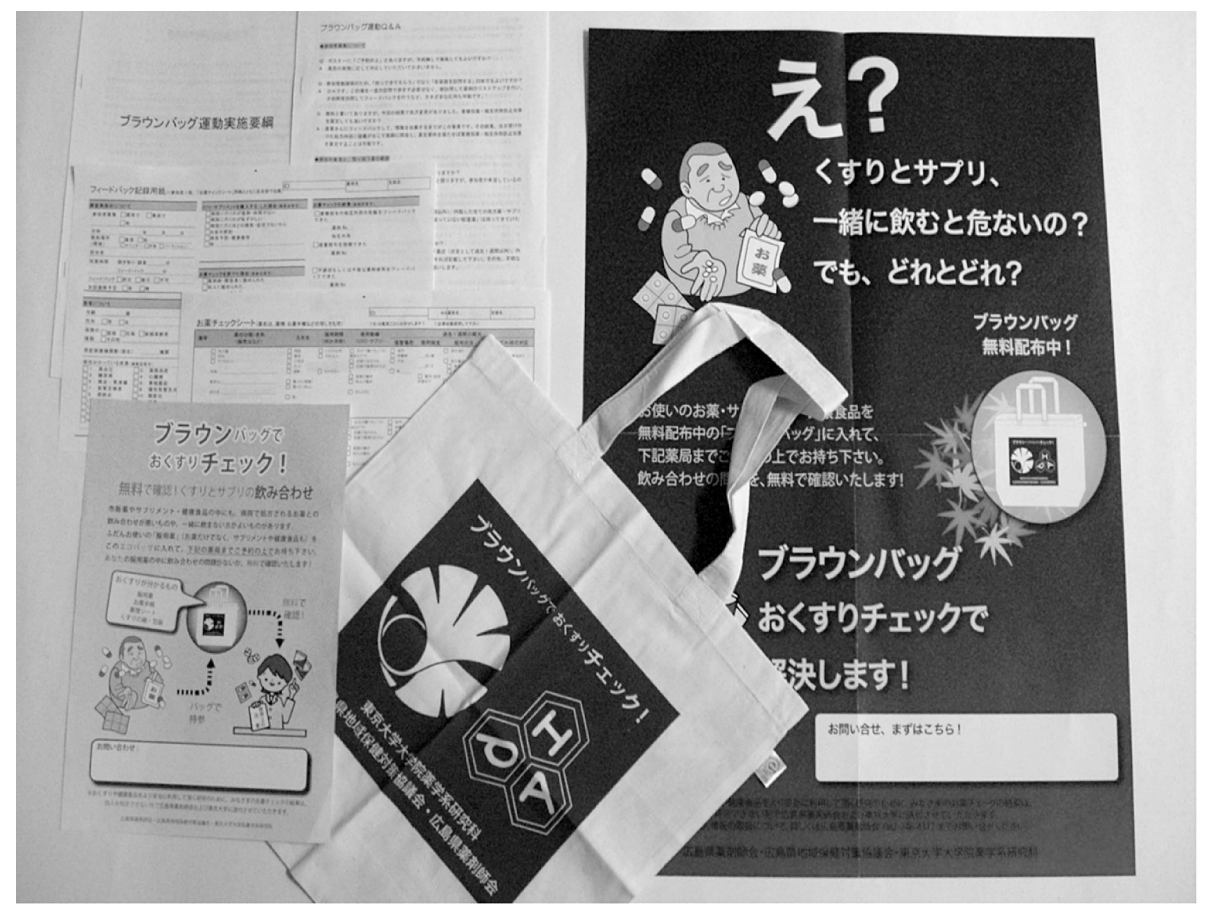

Fig. 1. Brown Bag Program Promotion Kit Used in Hiroshima

加してもらい，508 人の服用薬使用実態に関する データを集めた。 日本の高齢者の特徵として，5種 類以上の処方薬を同時に服用するポリファーマシー や健康食品やサプリメントの使用が多いことが明ら かになった。 また，併用注意が疑われる薬剤の組み 合わせが約 7 割の高齢者に認められ，薬剤師による 服用薬チェックの必要性が示された。この活動は, 茨城県土浦地区 (2010 年), 静岡県 (2011 年), 京 都府（2012 年), 兵庫県神戸市（2013 年）の薬局薬 剂師によって実施され，その後全国へと広がって いった。一方で，残薬の有効活用と薬剂費削減を目 的とした「節薬バッグ運動」が 2013 年から福岡市 薬剂師会を中心に実施された。厚生労働省の資料に よると，この取り組みによって薬剤費が約 $20 \%$ 削 減できることが報告され，それがエビデンスとなつ て「かかりつけ薬剤師」の役割として患者の服薬状 況の一元的管理の重要性が示された。日本でブラウ ンバッグ運動を始めてから約 6 年後のことであった.

この研究活動を通じて次の 3 つのことを学んだ. 1 つめは研究成果の見える化の重要性である，薬剤 師が行う研究は，「薬剤師がこんなに碩張つていま す」を主張するものが多い. しかし，臨床研究の本 来の目的は，薬剤師が何をやったかというプロセス を示すだけでは不十分で，患者にとってどんなメ
リットがあったのかをアウトカムとして示すことが 大切である. 2 つめは関係者の理解と連携である. 広島県で実施したブラウンバッグ運動では，最も多 くの事例を集めることができ，その成果を英文論文

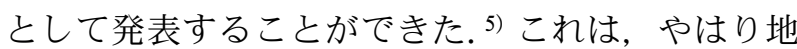
対協の先生方の協力が不可欠であった．3つめは メッセージの選択である。ブラウンバッグ運動は薬 物治療の適正化を目的に実施したが，節薬バッグ運 動では薬剤費削減を目指した。やはり後者がより メッセージ性が強く，それが調剤報酬におけるかか りつけ薬剂師につながつた。研究成果を医療政策に 反映させる成功事例だと思った。

\section{3. 薬剤師中間介入研究 (2013 年〜)}

患者宅にある大量の残薬の原因の 1 つとして慢性 疾患患者の長期処方があった。 薬局薬剤師としてこ の問題に対して何かできないかという考えから患者 登録制度を使つた追跡調査を 2013 年に開始した (Fig. 2)。この研究は日本アプライド・セラピュー ティクス（実践薬物治療）学会の保険薬局委員会と 保険薬局経営者連合会との共同プロジェクトとして 開始し，当初は 14 薬局の参加協力を得てパイロッ 卜研究から始めた。 ${ }^{6)}$ その後, 活動目的を「薬剤師 (Pharmacist）が次回受診時まで中間介入（Intermediate Intervention）することで，服薬状況や症 


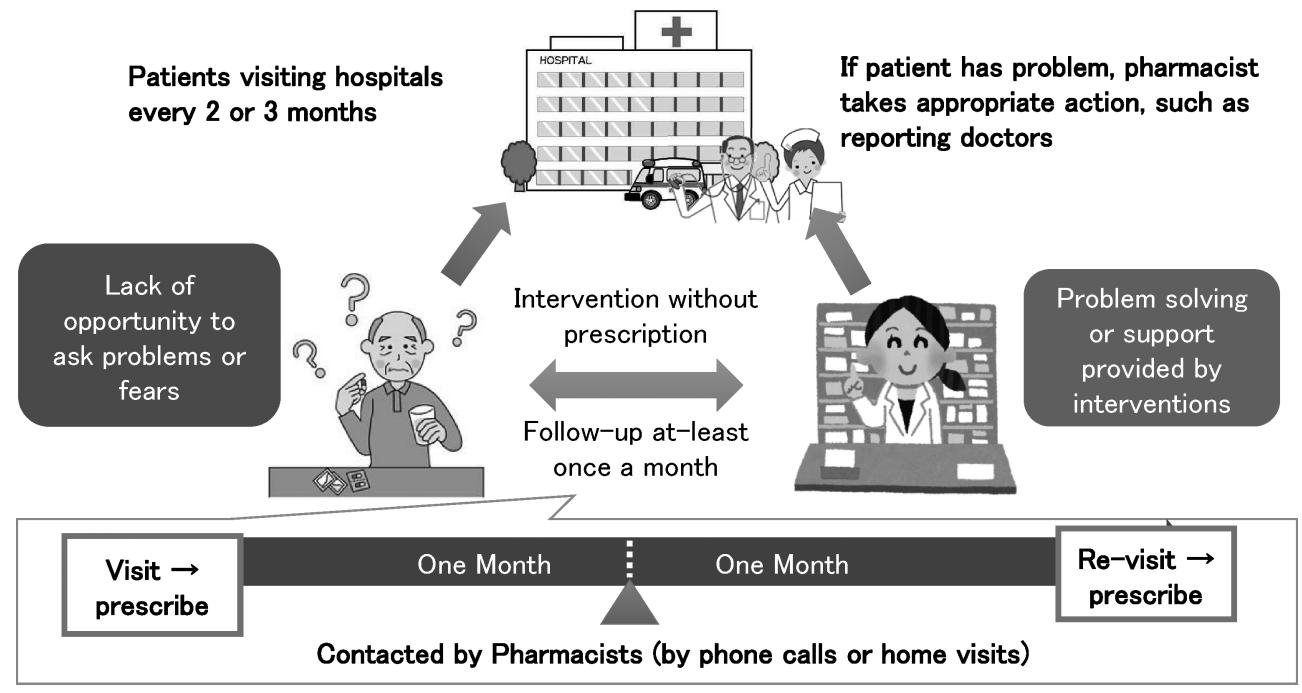

Fig. 2. Summary of Pharmacist Intermediate Intervention Study

状の改善，信頼関係の向上などに貢献できるかを研 究する (Study)」と定義し，英語の頭文字をつな げて PIIS と命名した．全国 128 薬局の参加協力が あり 158 名の患者登録と追跡調査を行った. ${ }^{7)}$ 登録 された患者には，服薬状況に懸念あり，薬物治療に 不安あり，生活状況や治療効果に問題ありなどの理 由が多く, 調剤時以外にも薬剤師と電話等で話すこ とで，お互いの信頼関係が構築され，薬のことだけ でなく患者生活に踏み込んだ情報収集ができるよう になり，時間とともに改善事例が増えていった．研 究対象や追跡方法などについて計画の微修正を行い ながら 2019 年までこの活動を続けた。研究活動に ついて情報発信を続けたことが影響したのか，2019 年末に成立した医薬品, 医療機器等の品質, 有効性 及び安全性の確保等に関する法律（薬機法）の改正 において，薬剤使用期間中の患者状態を確認する 「患者フォローアップ」が薬剤師業務として義務化 された。これもPIIS を始めてから約 6 年後のこと であった。

この研究活動からも多くのことを学ぶことができ た．例えば，すべての患者に同じように介入するの ではなく，介入すべき患者の見極めが大切なことで ある.このことはかかりつけ薬剤師がフォローアッ プの必要な患者を選択することにもつながる，次 に，介入成果を評価する方法を作ることの重要性で ある，薬局機能評価では，どうしても施設や行為基 準になり易いが，やはりアウトカム指標が欠かせな い. 最後に，介入内容やアウトカムについての記録
を残すことが大切である．薬剤師が書いたカルテゃ 薬歴の内容を，第三者が客観的に確認できるような 記録であれば，その記録を使った研究ができる。

\section{4. 病院薬剤師による臨床研究 (2020 年〜)}

薬局で行った $2 つ の$ 先行研究事例から, 介入や患 者の記録をどのように残すのかが臨床研究の質を大 きく左右することが示唆された，そこで，日常的に 患者記録を残している病院で薬剤師が行った $3 つ の$ 疫学研究から, 患者デー夕の重要性を考えてみたい. 1 つめの研究は，院内フォーミュラリーで定めた処 方プロトコールに基づいて実際の治療が行われてい るかを確認するために病院の電子カルテを使った研 究である. ${ }^{8)}$ この研究では, 非弁膜症性心房細動患 者での経口抗凝固薬の減量処方について添付文書の 基準通りに実施されているか否かを調査した。 6 力 月の調査期間に DOAC の処方記録のある 1063 名 の患者の診療内容を確認して，171 名に不適切な減 量が行われていることを確認した。同様に，過去 5 年間のカルテ情報を検索して DOAC 処方後に脳卒 中で入院した 20 名の患者の詳細について調べ，減 量のあつた 3 名の患者について症例解析を行つた. 2 つめの研究は，電子カルテ情報と薬剂部の記録を 組夕合わせて多剂処方の実態について評価した研究 である. ${ }^{9)}$ 入院中に薬剤種類数を減らすことで薬剤 総合評価調整加算を算定できた入院患者 72 名の記 録を利用して，減らすことのできた薬剤やその理由 について詳細な分析を行つた．また，退院後に外来 処方のあった患者 19 名については，その後の再投 
与の有無を確認して，入院中の減薬理由との関係に ついて評価した３つめは，糖尿病患者の栄養状態 と低血糖の発現リスクの関連性を評価するために電 子カルテを使った研究である. ${ }^{10)}$ 高齢者の栄養評価 法である geriatric nutritional risk index (GNRI) は, 入院患者の体重と血清アルブミンから簡便に計算で きる指標として複数の先行研究で使われていた。 そ れを糖尿病患者に応用して 1754 名の患者について 入院時の GNRI を計算して，入院中に低血糖が確 認された 81 名の栄養状態やその他の背景因子につ いて関連性を評価した。いずれの事例も研究に使え る詳細な患者デー夕を電子的に管理していたことか ら実臨床に役立つ研究につながつた。

5. 地域医療の場で薬剤師が行う臨床研究（まと めにかえて)

薬局薬剤師と病院薬剤師が行つた臨床研究につい て比較してみた。いずれも実臨床現場におけるアイ デアから生まれた研究で，患者医療に直接役立てる ことができるものである。しかしながら，日常業務 で作成する患者記録（カルテや薬歴）を研究に使え るか否かという点では大きな違いがあるように思え た，病院におけるカルテは，すべての医療関係者が 患者情報を共有することを前提に記録される，その ため，どのような介入（治療）が行われ，その結果 がどうなったのかを，第三者が記録を確認すること で（研究のために）後から把握することができる.

一方，薬局での記録は，過去に薬歴未記載問題が発 生したように，調剤報酬請求のための記録という側 面もあり，研究に使うための患者情報がきちんと記 録されているとは言い難かった。実際，ブラウン バッグ運動や薬剤師中間介入研究では，患者の個人 情報保護の観点から，薬局で作成している患者記録 (薬歴）を使って研究に必要な箇所のみを転記する 計画を立てた。しかし，データの欠損などから解析 段階で苦労することが多かった。薬局薬剤師に確認 すると，患者記録を第三者が後で確認することを想 定していないこともあり，研究に必要な記録が残さ れていないケースも少なからずあった。これでは薬 局にある患者記録を利用して質の高い臨床研究を行 うことは難しい.
近年，薬局薬剂師の業務は，処方箋を受けてから 調剤した薬剤を交付するという対物業務から，在宅 医療，副作用モニタリング，処方提案，残薬解消な ぞ，多岐にわたる対人業務にシフトしてきている. しかし，薬歴など患者記録の大切さやそれを活用し た客観的な評価などの議論はあまりない，病院での 患者カルテ記載は，一連の診療行為であり，患者記 録を残すことで業務が完結する。しかし，薬局では 患者対応に追われて患者記録が後回しになることも 少なくない．地域医療での臨床研究を実践すること で，正確なデー夕を残すことの意義を薬剤師が経験 から学ぶことができ，それが患者医療の質を高める ことにつながると思われる，日常診療の中でデータ を研究に使えるように残していく，それが地域包括 ケア時代に求められることである.

\section{利益相反＼cjkstart開示すべき利益相反はない.}

\section{REFERENCES}

1) Akazawa M., Imai H., Igarashi A., Tsutani K., Am. J. Geriatr. Pharmacother., 8, 146160 (2010).

2) Akazawa M., The Pharmaceuticals Monthly, 52, 849-853 (2010).

3) Akazawa M., The Journal of Public Health Practice, 81, 928-932 (2017).

4) Akazawa M., Medicine and Drug Journal, 53, 2688-2693 (2017).

5) Akazawa M., Nomura K., Kusama M., Igarashi A., Value Health Reg. Issues, 1, 98104 (2012).

6) Akazawa M., Mikami A., Tamura Y., Yanagi N., Yamamura S., Ogata H., Pharmacy (Basel), 6, 12 (2018).

7) Akazawa M., $R x$ Info, 26, 858-863 (2020) .

8) Ueda A., Toki S., Kitayama C., Akazawa M., Biol. Pharm. Bull., 43, 1135-1140 (2020).

9) Oki T., Saito A., Shono A., Sato H., Akazawa M., J. Drug Interaction Res., 44, 18-26 (2020).

10) Kimura Y., Kimura N., Akazawa M., Diabetol. Int., 12, 420-429 (2021). 